\title{
Influence of Soil Organic Matter Content on Mefenacet Concentration in Soil Water and the Phytotoxic Activity*
}

\author{
Naoki Nakamura**, Katsuichiro Kobayashi***, Ie Sung Shim*** \\ and Shizuo Nagatsuka***
}

\begin{abstract}
The influence of organic matter content on adsorption of mefenacet [2-(benzothiazol-2-yloxy)- $N$-methylacetanilide] to soil and the phytotoxic activity was studied in relation to the concentration in water of soil with varying organic matter content. Soil samples were prepared with different organic carbon content by mixing the original soil (Yawara paddy soil) with soil oxidized by hydrogen peroxide. The phytotoxic activity of mefenacet applied to the soils containing various amounts of organic matter decreased as the organic carbon content increased, and was correlated well with mefenacet concentration in soil water. Mefenacet adșorption on solid phase decreased with decrease in organic carbon. Its adsorption on organic matter was similar to that of the soils tested, except for the oxidized soil. These results suggested that phytotoxic activity of mefenacet applied to the soil is substantially induced by the herbicide concentration in the soil water which is dominated by its adsorption on organic matter.
\end{abstract}

* Parts of this work were reported at the 35 th Annual Meeting of the Weed Science Society of Japan in April, 1996 and supported in part by a Grant-in-Aid for Scientific Research from the Japan Society for the Promotion of Science.

** Doctoral Program in Agricultural Sciences, University of Tsukuba, Tsukuba, Ibaraki 305 , Japan.

*** Institute of Applied Biochemistry, University of Tsukuba, Tsukuba, Ibaraki 305, Japan.

(Received July 9, 1996)
Key words : Mefenacet, herbicide in soil water, organic matter content, adsorption on soil, herbicidal activity

\section{Introduction}

Mefenacet [2-(benzothiazol-2-yloxy)-Nmethylacetanilide] has a highly selective herbicidal activity to some weeds in transplanted rice paddy field ${ }^{1,2,11)}$. In our previous study $^{6}$, it was suggested that the herbicidal activity of soil-applied mefenacet was induced by its concentration in plant available soil water, and the adsorption of the herbicide on the soil was largely influenced by the organic matter content in the soil. A similar finding was reported for thenylchlor ${ }^{5,8)}$, and it is well known that herbicidal activity and adsorption on soil is influenced by soil organic matter content. Such content has been shown to be positively correlated with herbicide adsorption on soil and negatively correlated with the phytotoxicity ${ }^{3,4,9)}$. These studies, however, were carried out using soils taken from different places with various physico-chemical properties not only of organic matter content but also clay content, $\mathrm{pH}$, etc.

Yawara paddy soil and its oxidized soil with different organic matter content was used, and the influence of organic matter content on the phytotoxic activity of mefenacet, its adsorption on soil and concentration in soil water were evaluated: 


\section{Materials and Methods}

\section{Soil materials}

An air-dried fine earth $(<2 \mathrm{~mm})$ prepared from Ap-horizon of paddy soil (Yawara light clay), containing $42 \%$ clay, $30 \%$ silt and $28 \%$ sand in the size fractions, was used as the original soil sample in these experiments. This original soil sample will hereafter be referred to as soil $(\mathrm{Y})$. The organic matter was removed from soil(Y) by the hydrogen peroxide method ${ }^{7}$, after which the soil was washed with distilled water and again airdried to obtain organic matter removed soil, hereafter referred to as soil(C). To prepare the soil samples containing different ratios of organic carbon, soil(Y) and soil(C) were mixed at two different rates; these soils are hereafter referred to as soil(A) and soil(B), respectively. The physico-chemical properties and the organic carbon content of these soils are shown in Table 1. Soil pH was determined using soil water obtained through the centrifugation procedure described below. The changes in cation exchange capacity (CEC) and maximum water capacity are considered to depend on the change of organic matter content.

Application, extraction and determination of mefenacet

Application, extraction and determination of mefenacet were done employing the same

Table 1. Physico-chemical properties of the soil samples.

\begin{tabular}{ccccc}
\hline $\begin{array}{c}\text { Soil } \\
\text { sample }\end{array}$ & $\begin{array}{c}\text { Organic } \\
\text { carbon } \\
(\%)\end{array}$ & $\begin{array}{c}\mathrm{pH}^{*} \mathrm{O} \\
\mathrm{H}_{2} \mathrm{CEC}\end{array}$ & $\begin{array}{c}\mathrm{CE} \\
(\mathrm{cmol}) \\
(+) / \mathrm{kg})\end{array}$ & $\begin{array}{c}\text { Maximum } \\
\text { water capacity } \\
\text { (\% of dry soil) }\end{array}$ \\
\hline Soil (Y) & 4.2 & 6.5 & 25.0 & 80 \\
Soil (A) & 2.8 & 6.2 & 22.3 & 70 \\
Soil (B) & 1.4 & 6.3 & 18.4 & 64 \\
Soil (C) & 0.5 & 5.4 & 16.6 & 60 \\
\hline
\end{tabular}

*Soil pH was determined using soil water obtained through centrifugation. methods used in the previous study ${ }^{6}$. To recapitulate, the air-dried soil samples, containing different amounts of organic carbon, were put into an aqueous mefenacet solution and mixed thoroughly. The samples were then placed in plastic pots with holes in the bottom, and allowed to stand for 10 hours to reach maximum water capacity by the removal of water through gravitational means. These soil samples are hereafter referred to as applied-soils. The applied-soils were centrifuged in double tubes at $13,000 \times \mathrm{g}$ to separate them into plant available soil water (hereafter termed soil water) and soils remaining in the inner tube (hereafter termed centrifuged-soils). The amount of mefenacet was determined by HPLC, and the amount of mefenacet adsorbed on the centrifuged-soils was calculated by the method as described in the previous report ${ }^{6}$.

\section{Plant materials and bioassay}

Seeds of rice (Oryza sativa L. cv. Nipponbare) germinated in a petri dish at $25^{\circ} \mathrm{C}$ were used as a test plant ${ }^{6}$. The germinated seeds were planted and covered with the appliedsoil in the same plastic pots used to determine mefenacet in soil. These pots were then placed in an incubator $\left(25^{\circ} \mathrm{C}, 14 \mathrm{hr}\right.$.-illumination at about $70 \mu \mathrm{E} / \mathrm{m}^{2} / \mathrm{sec}$ ) for 3 days, and the shoot length of each seedling was measured. The experiments were done in three replications.

\section{Results and Discussion}

The relationship between rice growth and mefenacet concentration in treatment in the soil with various levels of organic carbon contents is shown in Figure 1. Rice growth in the control was similar to that among the test soils, but the phytotoxic activity of mefenacet was highest in $\operatorname{soil}(\mathrm{C})$ and decreased with increase in organic carbon con- 


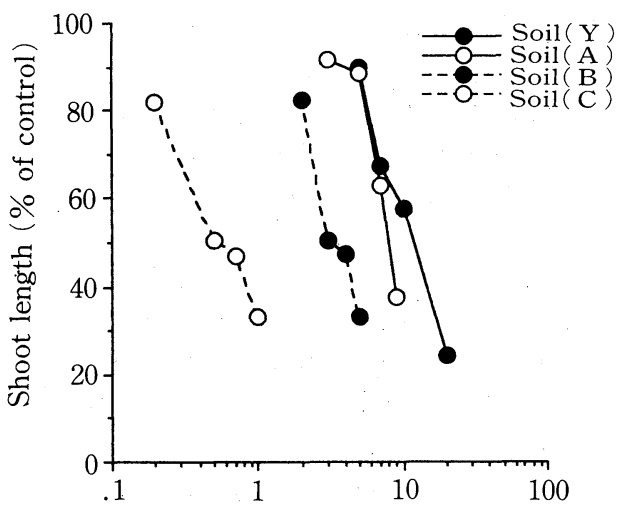

Concentration of mefenacet applied $(\mathrm{nmol} / \mathrm{ml})$

Fig. 1. Effect on rice growth in Yawara paddy soils with different organic carbon content by the amount of mefenacet applied.

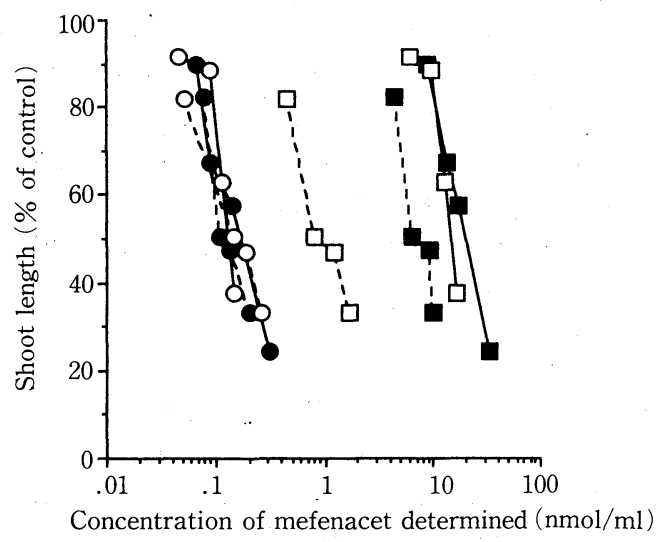

Fig. 2. Rice shoot growth as affected by the concentration of mefenacet in applied-soil and in soil water.

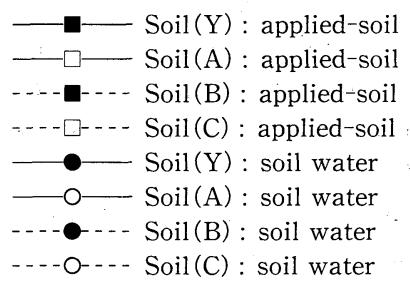

tent. This indicates that the phytotoxic activity and its relation to the concentration applied to the soil varied among the test soils. The phytotoxic activity similarly depended on mefenacet concentration in the soil water,
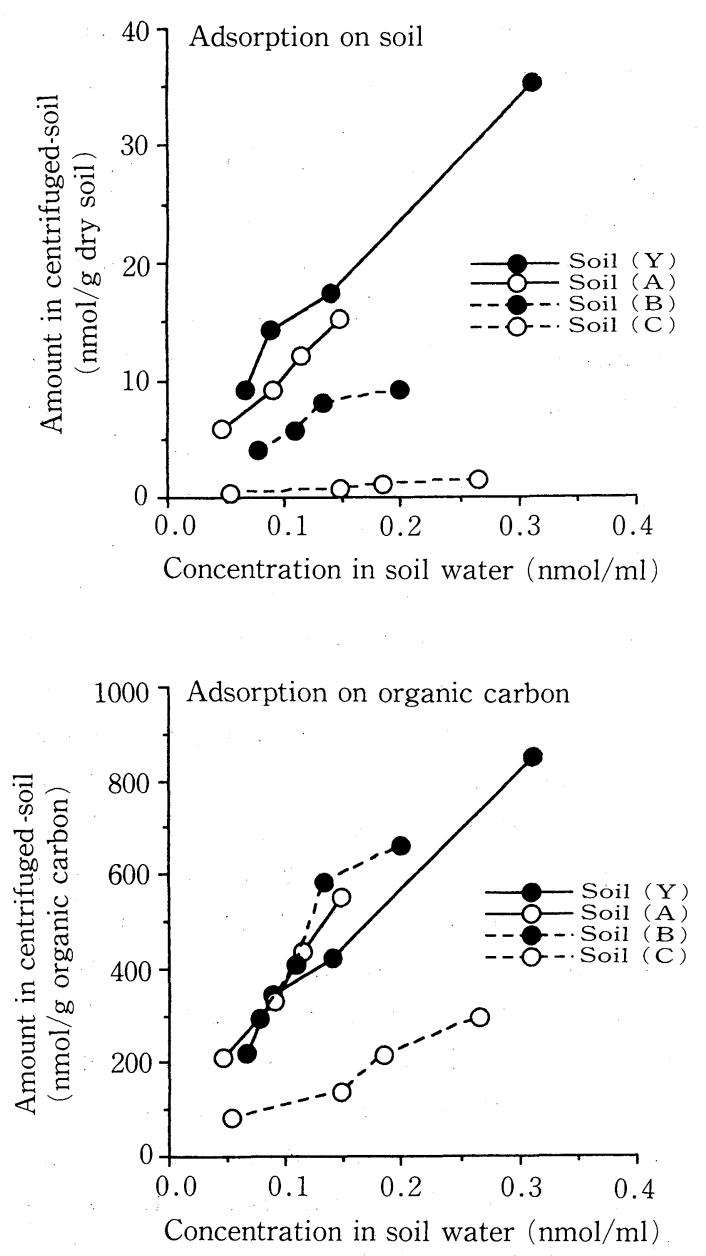

Fig. 3. Adsorption of mefenacet on the solid phase and on organic matter in soils of different organic carbon content.

but was differently affected by the herbicidal concentration in the applied test soil (Figure 2). It was suggested that the phytotoxic activity depended on the herbicide concentration in soil water but not on the concentration in applied-soil with different organic matter content.

The adsorption of mefenacet on soils with different organic carbon content is shown in Figure 3. Its adsorption on solid phase was highest in soil $(\mathrm{Y})$ and decreased with the reduction of organic carbon content. The 
adsorption on organic matter, on the other hand, was similar in each of the soils tested except in soil(C). It is assumed that the organic matter in soil(C) might be qualitatively different from that in other soils, because the organic matter remaining in this soil was not oxidized by hydrogen peroxide.

Many reports have demonstrated that the adsorption of an herbicide was related not only to organic matter but also to clay minerals as well as herbicidal content in the soil, as true of metolachlor [2-chloro- $6^{\prime}-$ ethyl- $N-\left(2-\right.$ methoxy-1-methylethyl) acet- $o^{-}$ toluidide $]^{10)}$. In our previous study ${ }^{6)}$ with mefenacet, it was demonstrated that the amount of adsorption on soil organic matter in Yawara light clay soil was identical to that of Ryugasaki sandy loam soil, although the adsorption on solid phase differed greatly between these soils. The results obtained in the present study indicated that the adsorption of mefenacet on Yawara paddy soil was dominated by the organic matter content in the soil but was little affected by other soil factors, supporting our suggestion ${ }^{6}$ that the adsorption on soil is primarily affected by the organic matter in soil.

It can be concluded that the concentration of mefenacet in soil water which determines its phytotoxic activity is strongly related to the organic matter content in the treated soil.

Acknowledgement: We are grateful to Nihon Bayer Agrochem Co., Ltd. for the gift of mefenacet.

\section{References}

1) Aya, M., K. Yasui, K. Kurihara, A. Kamochi and L. Eue 1987. Mefenacet - a new paddy herbicide. Proc. 10 th Asian-Pacific Weed Sci.Soc. Conf. 567-573.

2) Fedtke, C. 1987. Physiological activity spectra of existing graminicides and the new herbicide 2-(2-benzothiazolyl-oxy)- $N$-methyl- $N$ phenylacetamide (mefenacet). Weed Res. 27, 221-228.

3) Harrison, G.W., J.B. Weber and J.V. Baird 1976. Herbicide phytotoxicity as affected by selected properties of North Carolina soils. Weed Sci. 24, 120-126.

4) Hollist, R.L. and C.L. Foy 1971. Trifluralin interaction with soil constituents. Weed Sci. 19, 11-16.

5) Kobayashi, K., M. Onoe and H. Sugiyama 1994. Thenylchlor concentration in soil water and its herbicidal activity. Weed Res., Japan 39, 160-164.

6) Kobayashi, K., N. Nakamura, I.S. Shim and S. Nagatsuka 1996. Relationship of herbicidal activity of soil-applied mefenacet to the concentration in soil water and adsorption in soil. Weed Res., Japan 41 (in press).

7) Kozak, J., J.B. Weber and T.J. Sheets 1983. Adsorption of prometryn and metolachlor by selected soil organic matter fractions. Soil Sci. 136, 94-101.

8) Onoe, M., D.J. Lee, K. Kobayashi and H. Sugiyama 1995. Herbicidal activity of soilapplied thenylchlor and its mobility in two paddy soils. Weed Res., Japan 40, 75-79.

9) Pederson, H.J., P. Kudsk and A. Helweg 1995. Adsorption and $\mathrm{ED}_{50}$ values of five soil-applied herbicides. Pestic. Sci. 44, 131-136.

10) Pusino, A., W. Liu and C. Gessa 1992. Influence of organic matter and its clay com. plexes on metolachlor adsorption on soil. Pestic. Sci. 36, 283-286.

11) *Yasui, K. 1986. Hinokuroa (mefenacet)new herbicide for rice paddy field - (in Japanese). Pesticide Res. 33, 30-52.

* Translated from Japanese by the present authors 
メフェナセットの生育抑制効果および土壌水中 濃度に及ぼす土壤有機物含有量の影響

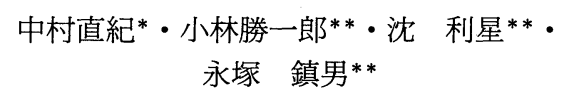

\section{摘 要}

谷和原水田土㗒に過酸化水素を加えて土䁃有機 物を分解除去することにより調製した有機物含有 量の異なる土壌を供試し,メフェナセット [2-(benzothiazolyl-2-yloxy)- $N$-methylacetanilide]の土 䗙吸着, 生育抑制効果および土壤水中濃度に及ぼす 有機物含有量の影響について検討した。

検定植物として供試したイネ（Oryza sativa cv. Nipponbare)の生育抑制効果を調べた結果, 有機炭 素含有量の小さい土壌ほど高い活性を示した（Fig. 1)。

生育試験に供試した土壤を二重遠心管を用いて 遠心分離し, 本剤の存在量を土壌水と遠心分離土壌

$*$ 筑波大学 農学研究科

** 筑波大学 応用生物化学系
とに分けて測定し, 生育抑制効果と本剤の存在量と の関連性を調べた結果, 生育抑制効果は有効水と想 定される土袞水中濃度と密接に関連していたが, 処 理土袞における存在量とは関連がなかった（Fig. 2)。また, 本剤の固相あたりの吸着は, 有機炭素含 有量の高い土壌で大きく, 有機炭素含有量の減少に ともなって低くなった。一方，土壤有機炭素あたり の吸着は, 過酸化水素分解土壇を除き, その他の供 試土壤間で一致する傾向を示し, 本剤の土壌吸着は ほとんどが有機炭素含有量に依存した吸着である ことが明らかとなった (Fig. 3)。

これらの結果から，メフェナセットの土壌吸着 は，ほとんどが土壤有機物に吸着されていることが 明らかにされた。また土壤に施用した本剤の生育抑 制効果は本剤の土壌水中濃度に依存して発現する が，その濃度は土壌有機物吸着により支配されてい るものと考えられる。

キーワード : メフェナセット, 土壌水中濃度, 有機 物含有量, 土壤吸着, 生育抑制 